\section{DIARY}

\section{SEPTEMBER}

2010 FDI Annual World Dental Congress

Date: 2-5 September 2010

Venue: Centro de Convencões da Bahia,

Salvador da Bahia, Brazil

Email:congress@fdiworldental.org

www.fdiworldental.org

BDA Northern Ireland Branch -

Meet the BDA Chief Executive

Date: 7 September 2010

Venue: Medical Biology Centre, Lisburn

Road, Belfast

Email: events@bda.org

www.bda.org/events

BDA Scottish Scientific Conference 2010

Date: 10 September 2010

Venue: Doubletree by Hilton, Dunblane

Email: events@bda.org

www.bda.org/events

Aesthetic dentistry for the GDP (Belfast)

Date: 17 September 2010

Venue: Ramada, Belfast

Email: cappiah@rcseng.ac.uk

www.fgdp.org.uk

Fall 2010 American Academy of Cosmetic Dentistry International Meeting/British Academy of Cosmetic Dentistry Annual Conference

Date: 23-25 September 2010

Venue: Hilton London Metropole Hotel, London

Email: info@bacd.com

www.aacdlondon.com

\section{OCTOBER}

BDPMA Autumn Seminars

Management Development

Date: 8, 13 October 2010

Venue: Manchester, Newcastle

Email: denise@bdpma.org.uk

www.bdpma.org.uk

Dental Protection: Discovering

the 'H' factor (human nature)

(techniques to manage difficult patients)

Date: 13 October 2010

Venue: City Hotel, Derry

Date: 14 October 2010

Venue: Belfast Waterfront, Belfast

Email: events@dentalprotection.org

www.dentalprotection.org/newsnevents/

events/hfactor

\section{BDA TO GUIDE ON CQC}

The Care Quality Commission's (CQC's) new system of registration requires all providers of primary dental care, including those from the NHS and private sectors, to be registered with them by 1 April 2011.

The British Dental Association (BDA) is running a one-day course delivered by a CQC representative and BDA experts, explaining the new application submis- sion process, answering questions and highlighting the key information and dates. The course will help dental professionals identify what they already have in place, what more they might need to do and when to develop an action plan.

The course is being held on 30 September in London and 21 October in Manchester. More details can be found at www.bda.org/training or by telephoning 02075634590.

\title{
STUDENTS ENCOURAGED TO FOCUS ON PREVENTION
}

Elaine Omand is the first winner of The Ivoclar Vivadent Prize in Preventive Dentistry at Dundee Dental School.

This annual undergraduate prize aims to encourage students to focus on the preventive aspects of dental caries, which are often overlooked in the quest for developing operative skills.

All Dundee third year dental students are invited to carry out a caries risk assessment of a patient under their care to assist the patient in making lifestyle changes for the benefit of their dental health. This involves taking a dietary history and culturing oral bacteria to assess the level of caries-producing bacteria using the Ivoclar CRT Test Kit. The impact of any changes made in response to this is highlighted to the patient by repeat testing a few months later.

'The prize reinforces the impact of simple preventive means in fostering good self dental care,' said Dr Graham Chadwick, who introduced the prize.

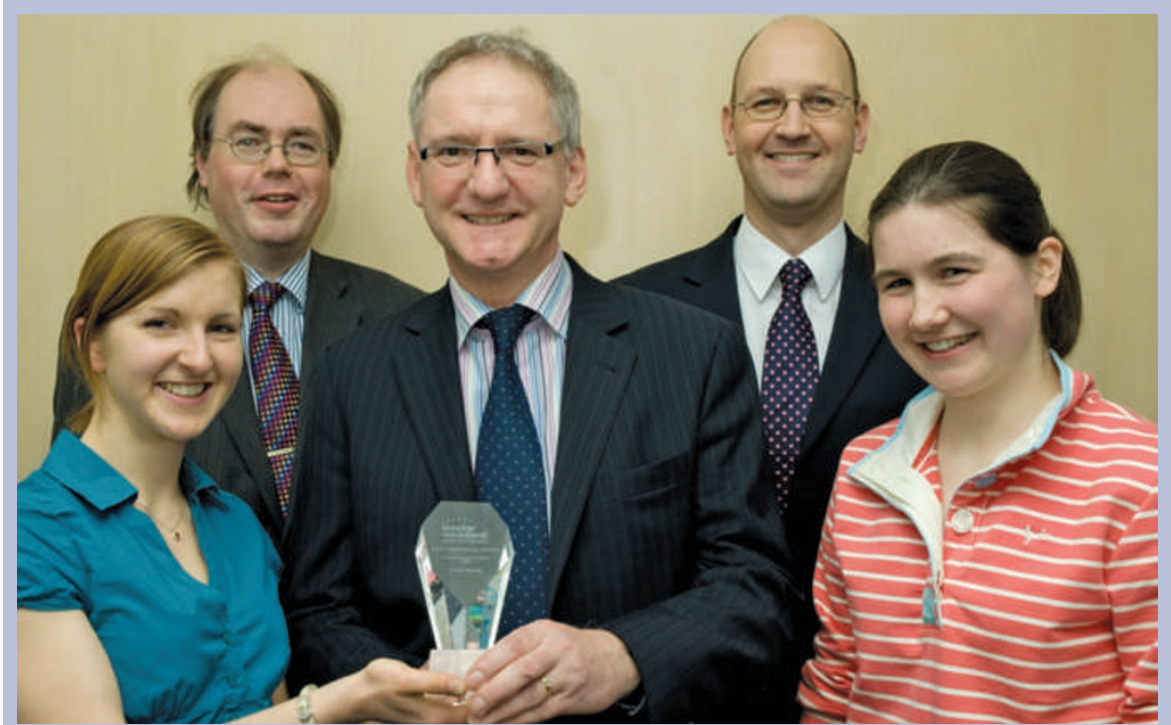

From left to right: Elaine Omand, Graham Chadwick (judge), Chris Parker of Ivoclar Vivadent, Andy Hall (judge) and Emily Mackie (runner up)

\section{ORTHODONTIC COMMISSIONING INVITE}

The British Orthodontic Society (BOS) is inviting primary care trusts (PCTs) and strategic health authorities (SHAs) to attend the second Orthodontic Commissioners Education Day which takes place alongside the BOS Conference in Brighton on 22 September 2010.

The focus will be on PDS orthodontic contract arrangements beyond 2011 in addition to Quality Assurance and the Vital Signs reports. See www.bos.org.uk. 